\title{
DETERMINATION OF CARBON EMISSIONS IN SHALLOW SOIL OF HARRAN PLAIN, TURKEY
}

\author{
DİLEKOĞLU, M. F. ${ }^{{ }^{*}}-$ SAKİN, E. ${ }^{2}$ \\ ${ }^{I}$ Department of Environmental Engineering, Faculty of Engineering of Harran University \\ Osmanbey Campus, 63200 Sanliurfa, Turkey \\ ${ }^{2}$ Department of Soil Science and Plant Nutrition, Agriculture Faculty of Harran University \\ Osmanbey Campus, 63200 Sanliurfa, Turkey \\ *Corresponding author \\ e-mail: dilekoglu@harran.edu.tr \\ (Received $4^{\text {th }}$ May 2017; accepted $25^{\text {th }}$ Jul 2017)
}

\begin{abstract}
Global climate change is known to be a result of atmospheric greenhouse gases. Thus, the atmospheric greenhouse gases should be reduced to prevent the climate change. Based on this fact, scientists have been working to reduce atmospheric greenhouse gases $\left(\mathrm{CO}_{2}, \mathrm{~N}_{2} \mathrm{O}, \mathrm{CH}_{4}\right)$. Due to the increases in $\mathrm{CO}_{2}$ emissions in agricultural lands, the interest in scientific research had moved to this field. In the present study, the shallow soil $\mathrm{CO}_{2}-\mathrm{C}$ emissions in Harran Plain were measured. The soil $\mathrm{CO}_{2}-\mathrm{C}$ emissions were measured weekly using the soda-lime method. The Mean soil $\mathrm{CO}_{2}-\mathrm{C}$ emission was $8.70 \pm$ $0.57 \mathrm{~g} \mathrm{~m}^{-2}$ week ${ }^{-1}$, according to the results obtained in the study. Climate data from the same period obtained that soil moisture was $17.21 \pm 2.05 \%$ and soil temperature was $12.87 \pm 1.80^{\circ} \mathrm{C}$. A very significant positive correlation was found between soil $\mathrm{CO}_{2}-\mathrm{C}$ emissions and soil temperature $(\mathrm{r}=0.049$; $\mathrm{p}<0.01)$ and there was very significant negative correlation between soil $\mathrm{CO}_{2}-\mathrm{C}$ emissions and soil moisture $(r=-0.196 ; p<0.01)$. There was a very strong statistically significant negative correlation $(r=-$ $0.854, \mathrm{p}<0.01)$ between soil moisture and soil temperature. While the soil $\mathrm{CO}_{2}-\mathrm{C}$ emissions decreased as the soil moisture increased, it increased with the soil temperature.
\end{abstract}

Keywords: atmospheric greenhouse, carbondioxide emission, terrestrial ecosystems, agricultural activities

\section{Introduction}

Soil respiration, which is an important part of the respiration in the ecosystem, is one of the most important processes in atmospheric carbon transport from terrestrial ecosystems to the atmosphere. (Fiedler et al., 2015). Carbon equilibrium in these ecosystems was defined as the balance between plant carbon loss due to plant and soil respiration and plant carbon intake (Beer et al., 2010; Luyssaert et al., 2007; Malhi et al., 1999; Le Quéré et al., 2009, 2014; Trumbore, 2006). The equilibrium value, in other words, carbon storage and carbon resource behavior of terrestrial ecosystems has been of great interest in climate change studies (Hashimoto et al., 2015).

Since the carbon cycle is a bio-geochemical phenomenon, it was stated that it is very difficult to predict the $\mathrm{CO}_{2}$ exchange between the biosphere and the atmosphere due to the complex relationships between physical, chemical and biological processes (Friedlingstein et al., 2006). Despite this complexity, carbon cycle studies and $\mathrm{CO}_{2}$ measurements are conducted with different methods at the present time. Patra et al. (2013) stated that verification of estimates could only be done at the point scale, in addition to the complexity of the system, because reliable data can only be obtained on site observations. Today, measurements are generally conducted with chamber-based 
methods. After measurements were taken, basic modeling was used and the $\mathrm{CO}_{2}$ emissions were estimated in the period between measurement dates (Beetz et al., 2013).

The main greenhouse gases that cause climate change and global warming are $\mathrm{CO}_{2}$, $\mathrm{CH}_{4}$ and $\mathrm{N}_{2} \mathrm{O}$ (Wu and Lee, 2011). The fossil fuel use, deforestation, industrial growth and agricultural activities increase atmospheric greenhouse gas emissions. The most important of these gases that have increased in the atmosphere since the industrial revolution, is $\mathrm{CO}_{2}$, which has increased by about $30 \%$ since 1750 . It is estimated that the amount of $\mathrm{CO}_{2}$ was $280 \mathrm{ppm}$ before the industrial revolution and it was $370 \mathrm{ppm}$ in 1999, and 380 ppm in 2007 (Houghton et al., 2007).

Efforts to determine the amount of soil $\mathrm{CO}_{2}$ emissions due to agricultural activities are increasing rapidly. Sakin and Sakin (2015) determined the average $\mathrm{CO}_{2}$ emissions in the clay soil of Sanliurfa-Harran Plain located in the arid and semi-arid Southeastern region in Turkey as $5.46 \mathrm{~g} \mathrm{~m}^{-2}$ day $^{-1}$ at $0-5 \mathrm{~cm}$ depth based on soil temperature and moisture. A positive correlation between soil $\mathrm{CO}_{2}$ emission and soil temperature, and a negative relationship between soil $\mathrm{CO}_{2}$ emission and soil moisture were also found in the abovementioned study. Zhou et al. (2015) reported that an increase in soil temperature and microorganism activities caused increased decay and decomposition.

High emissions values were determined in studies conducted in arid and semi-arid environmental conditions. Allaire et al. (2012) recorded 9.31-11.5 $\mathrm{g} \mathrm{CO}_{2} \mathrm{~m}^{-2} \mathrm{day}^{-1}$ emissions in semi-arid climate shrubland and shrubbery and $5.48 \mathrm{~g} \mathrm{CO}_{2} \mathrm{~m}^{-2}$ day $^{-1}$ emissions in grasslands. Weekly $\mathrm{CO}_{2}$ emissions fluctuated during the growth season in a study conducted in pasture areas in arid regions of China, and it was determined as average $2.4 \mathrm{~g} \mathrm{CO}_{2} \mathrm{~m}^{-2} \mathrm{day}^{-1}$. In semi-arid regions in Spain, 4.07-15.43 $\mathrm{g} \mathrm{CO}_{2} \mathrm{~m}^{-2}$ day $^{-1}$ emission was recorded (Curiel Yuste et al., 2003)

Sakin (2016) measured the $\mathrm{CO}_{2}$ emissions based on soil temperature and moisture in semi-arid uncultivated soil in the Southeastern region in Turkey. Based on that study, the soil moisture at $5 \mathrm{~cm}$ soil depth was $11.66 \%$ and the soil temperature was $22.53^{\circ} \mathrm{C}$, while soil $\mathrm{CO}_{2}$ emission was $7.94 \mathrm{~g} \mathrm{~m}^{-2}$ day $^{-1}$. Soil $\mathrm{CO}_{2}$ emissions has a positive correlation with soil temperature and a negative correlation with soil moisture. In the study, the maximum $\mathrm{CO}_{2}$ emissions were observed in February and the minimum emissions was observed in August. The soil $\mathrm{CO}_{2}$ emissions demonstrated annual fluctuations based on climatic parameters. It was stated that the climate change has emerged as a result of annual fluctuations.

Celik et al.(2017) reported in arid and semi-arid climate regions, soil carbon content is generally low because of the factors such as insufficient precipitation, low biomass and organic carbon intake, high oxidation, use of soil biomass as animal feed, being picked up for burning or as fuel. On the other hand, clayey nature of the soils is significant in terms of SOC content and accumulation. Clay surrounds SOC, and creates organo-mineral complexes, and protects the soil against decomposition and disintegration.

Turkey has quite large agricultural areas. The objective of the present study was to determine shallow soil $\mathrm{CO}_{2}$ emissions due to climatic factors in Southeastern Turkey.

\section{Material and Method}

\section{Study area}

The study area is a part of "Harran Plain" on South East of Turkey. It is located between $37^{\circ} 10^{\prime} 14^{\prime}$ 'N latitude and $39^{\circ} 00^{\prime} 14^{\prime \prime}$ E longitude (Fig. 1). The altitude of the test area, which is located on a flat and near-flat topography, is $507 \mathrm{~m}$. The region's 
summers are arid and hot, and winters are temperate and with low-precipitation. Precipitation is not sufficient for agricultural cultivation during certain years. The mean annual precipitation is $448.11 \mathrm{~mm}$, the annual average maximum temperature is measured as $41.12^{\circ} \mathrm{C}$ in July, and the lowest temperature is measured as $2.41^{\circ} \mathrm{C}$ in February. Annual mean relative humidity was the highest at $92.32 \%$ and the lowest at $33.29 \%$ (TSMS, 2016).

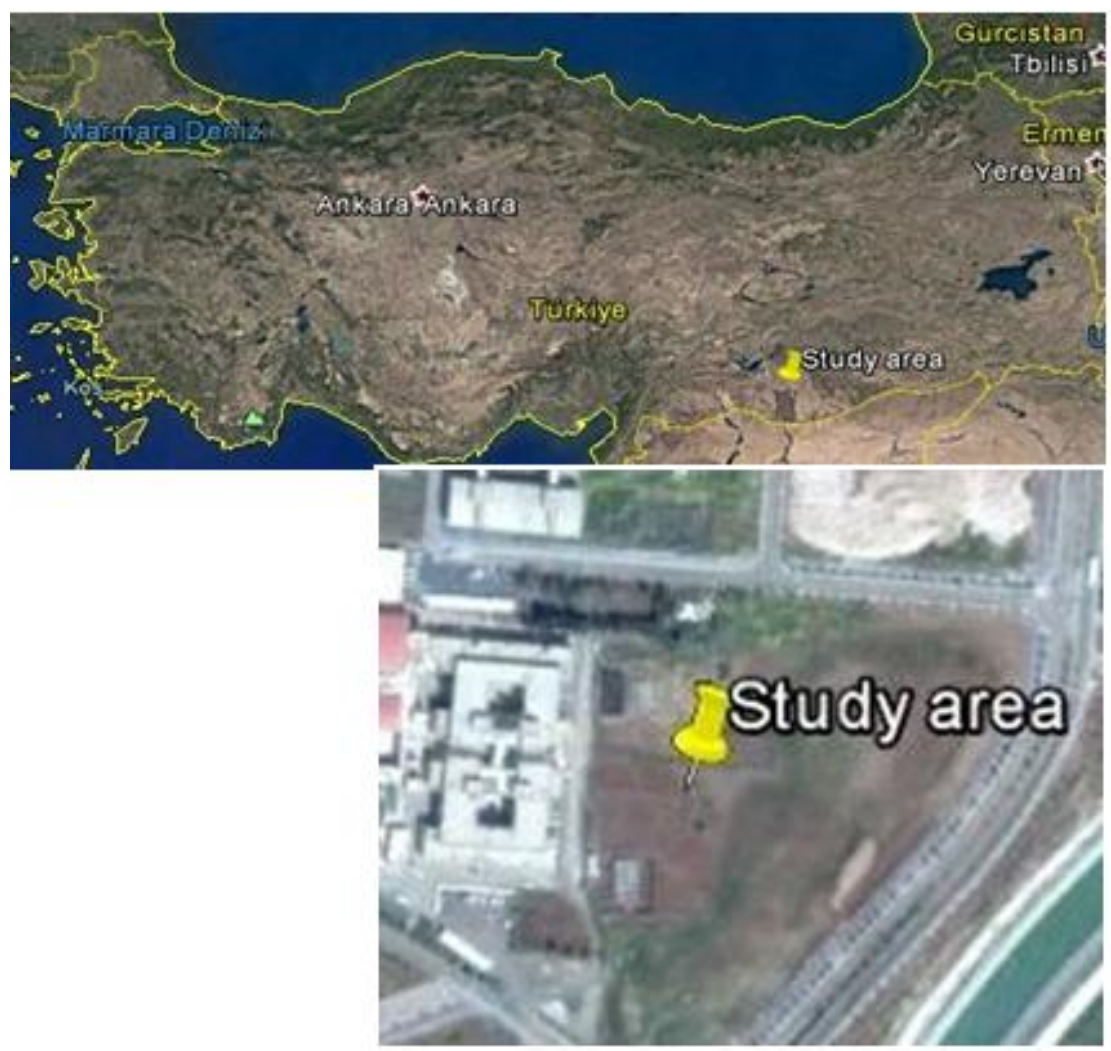

Figure 1. Location of the study area

\section{Laboratory analyses}

It was determined that the soil reaction $(\mathrm{pH})$ of the experimental soil was 7.30 , electrical conductivity (EC) was $52.60 \mu \mathrm{S} \mathrm{cm}$, organic carbon content was $0.8 \%$, cation exchange capacity was $35.15 \mathrm{cmol} \mathrm{kg}^{-1}$. Among the exchangeable cations, calcium amount was the highest and potassium amount was the lowest. The particle fractions of the soil included mostly clay-sized particles.

The amount of soda-lime considered in the studies varies based on the ecological conditions, but $50 \mathrm{~g}$ of soda-lime was taken for the present study. The study was set up in the Faculty of Agriculture experiment area in 3 replicates and the calculations were made based on the following equation.

$$
E_{C O_{2}}=\frac{\left(S L_{a d}-S L_{i n i}\right) \times W C}{(A \times t)}
$$


Where;

$E_{\mathrm{CO}_{2}}$ is the total amount emitted during the incubation period $\left(\mathrm{g} \mathrm{CO}_{2} \mathrm{~m}^{-2}\right.$ day $\left.^{-1}\right)$;

$S L_{a d}$ is $\mathrm{CO}_{2}$ adsorbed soda-lime amount $(\mathrm{g})$;

$S L_{\text {ini }}$ is the initial soda-lime amount $(\mathrm{g})$;

$\mathrm{A}$ is the area of measurement $\left(\mathrm{m}^{2}\right)$;

$\mathrm{t}$ is the incubation time (the time past in the field) (day) and;

WC is water correction number was taken as 1.69.

\section{Results and Discussion}

Weekly soil $\mathrm{CO}_{2}-\mathrm{C}$ emissions varied between $6.21-17.22 \pm 0.57 \mathrm{~g} \mathrm{~m}^{-2}$ week $^{-1}$, soil temperatures varied between $5.33-28.28 \pm 1.80^{\circ} \mathrm{C}$ and weekly soil moisture varied between 7.05-29.89 \pm 2.05 (Table 1). As the soil moisture increased, soil temperature decreased, and as a result, soil $\mathrm{CO}_{2}$ emissions decreased. Maximum soil $\mathrm{CO}_{2}-\mathrm{C}$ emission was determined when the soil moisture was $7.71 \%$ and soil temperature was $18.58^{\circ} \mathrm{C}$, while the minimum emission was determined when the soil moisture was $29.89 \%$ and soil temperature was $6.39^{\circ} \mathrm{C}$. Soil emissions are not only dependent on soil temperature and moisture factors but also on other soil properties. Soil $\mathrm{CO}_{2}-\mathrm{C}$ production was reported to be the result of plant root respiration and microbial degradation of organic carbon, and these factors were dependent on the soil temperature and moisture (Davidson et al., 2006). In previous studies conducted in the region, it was reported that the soil emissions varied based on the soil temperature and moisture, consistent with the findings of the present study (Sakin, 2016; Sakin et al., 20015, Sakin and Sakin, 2015; Gülle Sakin et al., 2015).

Soil is a heterogeneous medium that consists of gas, liquid and solid phases and varies in depth. The $\mathrm{CO}_{2}$ transport in the soil occurs straight from the bottom to the soil surface. Thus, the $\mathrm{CO}_{2}$ transported to the surface is released to the atmosphere. Soil $\mathrm{CO}_{2}$ density varies based on the depth of the soil. In general, deep soil has a high $\mathrm{CO}_{2}$ concentration, while in exposed (shallow) soil it is low. The soil $\mathrm{CO}_{2}$ density in deep soil is about 100 times $(6 \%-8 \%)$ the density on the soil surface. However, the amount of $\mathrm{CO}_{2}$ resulting from the activities of organisms and roots is higher in the surface layer than in the sub layer (Allaire et al., 2012). Since the surface of the soil is rich in organic waste, life prospers more in this layer. Comparisons that were conducted in the present study confirmed this fact. In uncultivated fields, soil $\mathrm{CO}_{2}$ emissions were about $20 \%$ higher than the cultivated areas in the current study.

Table 1. Descriptive Statistics of soil factors (weekly.

\begin{tabular}{cccccc}
\hline & Minimum & Maximum & Mean & Std. Error & Std. Deviation \\
\hline $\mathrm{CO}_{2}$ emission $\left(\mathrm{g} \mathrm{m}^{-2} \mathrm{week}^{-1}\right)$ & 6.21 & 17.22 & 8.70 & 0.57 & 2.40 \\
Soil Moisture $(\%)$ & 7.05 & 29.89 & 17.21 & 2.05 & 8.68 \\
Soil Temperature $\left({ }^{\circ} \mathrm{C}\right)$ & 5.33 & 28.28 & 12.87 & 1.80 & 7.64 \\
\hline
\end{tabular}

In a study conducted in clay textured vineyards in Harran Plain, weekly soil $\mathrm{CO}_{2}-\mathrm{C}$ emissions based on soil moisture and temperature $\left(5.81-21.23\right.$ and $\left.5.65-40.88^{\circ} \mathrm{C}\right)$ were measured between $4.94-20.97 \mathrm{~g} \mathrm{~m}^{-2}$ week $^{-1}$. It was stated that the effect of soil moisture and temperature on soil $\mathrm{CO}_{2}-\mathrm{C}$ emissions cannot be ruled out, but the emission 
is not entirely dependent on these two parameters (Carlisle et al., 2006; Gaertig et al., 2002; Davidson and Janssens , 2006; Ricardson et al., 2012). $\mathrm{CO}_{2}$ emissions were measured in an incubation study that was conducted to determine the correlation between $\mathrm{CO}_{2}$ emissions in arid and semi-arid sites and the temperature and humidity factors influencing these emissions. Soil specimens were incubated under different humidity and temperature conditions and it was found that soil $\mathrm{CO}_{2}$ emissions increased by $50 \%$ due to different moisture regimes where the soil temperature was kept constant (Conant et al., 2004).

The correlation between the weekly soil $\mathrm{CO}_{2}-\mathrm{C}$ emissions, soil moisture and soil temperature is given in Tables 2 and 3. Based on this information, there was a strong negative correlation between the soil carbon emission and soil moisture $(r=-0.196 ; p$ $<0.01$ ) and there was a positive correlation between the soil carbon emission and soil temperature $(r=0.049 ; \mathrm{p}<0.01)$. As the soil moisture increased, soil temperature and activity decreased, and the opposite was true for soil temperature. Soil temperature and moisture should be at a suitable level for living organisms in the soil. It is considered that living conditions of plant roots and organisms are suppressed at extreme conditions.

Table 2. Correlations between soil factors

\begin{tabular}{llcc}
\hline \multicolumn{1}{c}{ Soil factors } & & Soil Moist. (\%) & $\begin{array}{c}\text { Soil Temperature } \\
\left({ }^{\circ} \mathbf{C}\right)\end{array}$ \\
\hline $\mathbf{C O}_{\mathbf{2}}$ emission $\left(\mathbf{g ~ m}^{-\mathbf{2}}\right.$ week $\left.^{-\mathbf{1}}\right)$ & Pearson Correlation & -0.196 & 0.049 \\
& Sig. (2-tailed) & 0.00 & 0.00 \\
Soil Moisture (\%VWC) & Pearson Correlation & 1 & -0.854 \\
& Sig. (2-tailed) & 0.00 & 0.000 \\
\hline
\end{tabular}

Table 3. One-Sample Test between factors

\begin{tabular}{|c|c|c|c|c|c|c|}
\hline \multirow[t]{3}{*}{ Soil factors } & \multicolumn{6}{|c|}{ Test Value $=0$} \\
\hline & \multirow[b]{2}{*}{$\mathrm{t}$} & \multirow[b]{2}{*}{$\mathrm{df}$} & \multirow[b]{2}{*}{ Sig. (2-tailed) } & \multirow[b]{2}{*}{ Mean Difference } & \multicolumn{2}{|c|}{$\begin{array}{c}95 \% \text { Confidence } \\
\text { Interval of the Difference }\end{array}$} \\
\hline & & & & & Lower & Upper \\
\hline $\mathrm{CO}_{2}$ emission $\left(\mathrm{g} \mathrm{m}^{-2}\right.$ week $\left.^{-1}\right)$ & 15.38 & 106 & .000 & 8.70 & 7.51 & 9.89 \\
\hline Soil Moisture (\% VWC) & 8.41 & 106 & .000 & 17.21 & 12.89 & 21.53 \\
\hline Soil Temperature $\left({ }^{\circ} \mathrm{C}\right)$ & 7.14 & 106 & .000 & 12.87 & 9.07 & 16.67 \\
\hline
\end{tabular}

One of the important sources of soil respiration is roots and the second is the microbial respiration (Hanson et al., 2000) and 50\% of soil respiration is attributed to plant root respiration (Hanson et al., 1993). Carbon decomposition and decay and $\mathrm{CO}_{2}$ emissions by organisms are dependent on temperature and it was suggested to determine this correlation (Davidson et al., 2006). It was stated that the optimum temperature for soil respiration and organism activities, $35^{\circ} \mathrm{C}$ (Cable et al., 2011) is sufficient, however in certain areas the temperature is over $35^{\circ} \mathrm{C}$. There are also researchers who argued that the optimum temperature for optimum soil respiration should be above $35^{\circ} \mathrm{C}$ (Barraon-Gafford et al., 2011).

In the arid and semi - arid Southeastern Turkey, the soil carbon (C) emissions based on soil moisture $(12.89 \pm 0.56)$ and soil temperature $(18.19 \pm 2.07)$ was measured in the clayey soil of Sanliurfa - Harran Plain. There was a positive correlation between the soil 
$\mathrm{CO}_{2}-\mathrm{C}$ emissions and the soil temperature, and a negative relationship between soil $\mathrm{CO}_{2}-\mathrm{C}$ emissions and the soil moisture. An increase in soil temperature resulted in an increase in microorganism activities, decomposition and decay (Zhou et al., 2015). Nobrega et al. (2016) reported that high soil carbon emissions were not related to the high carbon content in the soil, but rather were influenced by anthropogenic factors, however these factors prevented carbon intake of the soil. As a result, the soil carbon emissions results from carbon decomposition by the plant roots and microorganisms in the soil. Buerkert et al. (2012) found that soil carbon emissions were 3-5 times the initial amount after the first irrigation.

Sakin et al. $(\mathrm{P}<0.05)$ determined a significant positive correlation between $\mathrm{CO}_{2}$ emissions and relative moisture and the moisture inside the PVC container $(\mathrm{p}<0.05)$, and a very significant negative correlation between $\mathrm{CO}_{2}$ emissions and relative temperature and PVC container internal temperature $(\mathrm{p}<0.01)$. An inverse correlation was identified between the relative humidity, relative temperature and PVC container internal temperature. In a study by Akburak (2008) conducted in the Belgrade forest in Istanbul, a weak positive correlation was found between soil $\mathrm{CO}_{2}$ emissions and soil moisture and a negative relationship between soil $\mathrm{CO}_{2}$ emissions and soil temperature. When soil respiration was above $10 \%$ of soil moisture content, a positive correlation was found between soil $\mathrm{CO}_{2}$ emissions and soil temperature $(\mathrm{p}<0.01)$. On the other hand, there was a positive correlation between soil water content and respiration when soil temperature was above $16^{\circ} \mathrm{C}$ in all land uses $(\mathrm{p}<0.001)$. In dry periods, there was a negative relationship between soil emissions and soil temperature (Almagro, 2009). Similar results were obtained in the current study.

\section{Conclusion}

A very significant negative correlation was found between soil $\mathrm{CO}_{2}-\mathrm{C}$ emissions and soil moisture and a very significant positive correlation was found between soil $\mathrm{CO}_{2}-\mathrm{C}$ emissions and soil temperature. There was a very strong statistically negative correlation between soil moisture and soil temperature. The soil $\mathrm{CO}_{2}-\mathrm{C}$ emissions decreased as the soil moisture increased while it increased as the soil temperature increased.

At the point where the soil moisture and temperature are at their maximum, soil $\mathrm{CO}_{2}$ $-\mathrm{C}$ emissions are neither maximum nor the minimum. The soil $\mathrm{CO}_{2}-\mathrm{C}$ emissions are the result of microbial activities of the organic carbon and plant roots in the soil, and the activities of the organisms that live in the soil. Thus, soil temperature and soil moisture should be optimum for the living beings in the soil.

The soil $\mathrm{CO}_{2}-\mathrm{C}$ emissions increase or decrease due to the suppression of the optimum conditions for the living organisms in the soil when the soil temperature and the soil moisture are minimum and maximum. In studies similar to the present one, the objective is to establish measures to determine and then reduce $\mathrm{CO}_{2}-\mathrm{C}$ emissions. If the soil $\mathrm{CO}_{2}-\mathrm{C}$ emissions decrease with the increase in soil moisture, it does not mean that we should keep the soil submerged in water. Or, since the emissions are at the minimum under the maximum soil temperature, we cannot keep the soil constantly hot and without moisture. Thus, the idea of reducing the soil $\mathrm{CO}_{2}-\mathrm{C}$ emissions when the optimum conditions for the living beings in the soil are not available should be developed. 
Appropriate agricultural techniques should be used to reduce soil $\mathrm{CO}_{2}-\mathrm{C}$ emissions such as no - tillage, direct sowing and conservation agriculture techniques. Carbon dioxide measurements from soil should be made more healthful with modern equipment and more precise work. In arid and semi-arid climate regions, atmospheric $\mathrm{CO}_{2}-\mathrm{C}$ should be given to the context of atmospheric $\mathrm{CO}_{2}-\mathrm{C}$ to the soil through irrigation.

\section{REFERENCES}

[1] Allaire, S.E., Lange, S.F., Lafond, J.A., Pelletier, B. (2012): Athyna N. Cambouris d, Pierre Dutilleul Multiscalespatial variability of $\mathrm{CO}_{2}$ emissions and correlations with physico-chemical soil properties. - Geoderma 170: 251-260.

[2] Akburak, S. (2008): Belgrad ormanında farklı ağaç türleri altında toprak solunumunun mevsimsel değişimi. - İstanbul Üniversitesi, Fen Bilimleri Enst. Doktora tezi, 168s.

[3] Almagro, M., Lo'Pez, J., Querejeta, J.I., Marti'Nez-Mena, M. (2009): Temperature dependence of soil $\mathrm{CO}_{2}$ efflux is strongly modulated by seasonal patterns of moisture availability in a Mediterranean ecosystem. - Soil Biology \& Biochemistry 41: 594-605.

[4] Barron-Gafford, G.A., Scott, R.L., Jenerette, G.D., Huxman, T.E. (2011): The relative controls of temperature, soil moisture, and plant functional group on soil $\mathrm{CO}_{2}$ efflux at diel, seasonal, and annual scales. - Journal of Geophysical Research 116, 10-23.

[5] Beer, C., Reichstein, M., Tomelleri, E., Ciais, P., Jung, M., Carvalhais, N., ...\& Bondeau, A. (2010): Terrestrial gross carbon dioxide uptake: global distribution and covariation with climate. - Science 329(5993), 834-838.

[6] Buerkert, A., Jahn, H., Golombek, SD., Rawahi, MNA., Gebauer, G. (2012): Carbon and nitrogen emissions from stored manure and cropped fields in irrigated mountain oases of Oman. - Journal of Agriculture and Rural Development in the Tropics and Subtropics 111 (1):55-63.

[7] Beetz, S., Liebersbach, H., Glatzel, S., Jurasinski, G., Buczko, U., Hoper, H. (2013): Effects of land use intensity on the full greenhouse gas balance in an Atlantic peat bog. Biogeosciences 10(2): 1067-1082.

[8] Cable, J.M., Ogle, K., Lucas, R.W., Huxman, T.E., Lork, M.E., Smıth, S.D., T1ssue, D.T., Ewers, B.E., Pendall, E., Welker, J.M., Charlet, T.N., Cleary, M., Grıffith, A., Nowak, R.S., Rogers, M., Steltzer, H., Sullivan, P.F., Vangestel, N.C. (2011): The temperature responses of soil respiration in deserts: a seven desert synthesis. - Biogeochemistry 103:71-90.

[9] Carlisle, EA., Steenwerth, K., Smart, DR. (2006): Effects of land use on soil respiration: Conversion of oak woodlands to vineyards. - J. Environ. Qual. 35:1396-1404.

[10] Curiel Yuste, J., Baldocchi, D.D., Gershenson, A., Goldstein, A., Misson, L., Wong, S. (2007): Microbial soil respiration and its dependency on carbon in puts, soil temperature and moisture. - Global Change Biology 13:2018-2035.

[11] Celik, A., Sakin, E.D., Sakin, E., Seyrek, A. (2017): Surface carbon stocks of soil under pistachio cover on southeastern Turkey. - Applied Ecology and Environmental Resaerch 15(3): 747-758, DOI: http://dx.doi.org/10.15666/aeer/1503_747758

[12] Conant, R.T., Dalla-Betta, P., Klopatek, C.C., Klopatek, J. M. (2004): Controls on soil respiration in semiarid soils. - Soil Biology \& Biochemistry $36: 945-951$.

[13] Davidson, EA., Janssens, IA. (2006): Temperature sensitivity of soil carbon decomposition and feedbacks to climate change. - Nature 440:165-173.

[14] Fiedler, S.R., Buczko, U., Jurasinski, G., Glatzel, S. (2015): Soil respiration after tillage under different fertilizer treatments-implications for modeling and balancing. - Soil and Tillage Research 150:30-42.

[15] Friedlingstein, P., et al. (2006): Climate-carbon cycle feedback analysis: Results from the C4MIP model intercomparison. - J. Clim. 19: 3337-3353, doi:10.1175/JCLI3800.1. 
[16] Gaertig, T., Schak-Kirchner, H., Hildenbrand E.E., and Wilpert, K.V. (2002): The impact of soil aeration on oak decline in southwestern Germany. - For. Ecol. Manage. 159:15-25.

[17] Gülle Sakin, ED., Şaylan, L., Sakin, E., Altun, ŞB., Yeşilköy, S. (2015): Topraktan karbondioksit emisyonu ve meteorolojik değişkenler: Şanlıurfa örneği. - Uluslararası Katılımlı Toprak ve Su Kongresi, 01-04 Şubat 2015, Maraş.

[18] Hanson, P.J., S.D. Wullschleger, S.A. Bohlman., Todd, D.E. (1993): Seasonal and topographic patterns of forest floor $\mathrm{CO}_{2}$ efflux from an upland oak forest. - Tree Physiology 13:1-15.

[19] Hanson, P.J., Edwards, N.T., Garten, C.T., Andrews, J.A. (2000): Separating root and soil microbial contributions to soil respiration: Rev. methods and observations. - Biogeochem. 48: 115-146.

[20] Hashimoto, S., Carvalhais, N., Ito, A., Migliavacca, MC,. Nishina, K., Reichstein, M., (2015): Global spatiotemporal distribution of soil respiration modeled using a global database. - Biogeosciences 12: 4121-4132.

[21] Houghton, R. A. (2007): Balancing the Global Carbon Budget. - Annual Review of Earth and Planetary Sciences 35: 313 - 347.

[22] Luyssaert, S., Inglima, I., Jung, M., Richardson, A. D., Reichstein, M., Papale, D., ... \& Aragao, L. E. O. C. (2007): $\mathrm{CO}_{2}$ balance of boreal, temperate, and tropical forests derived from a global database. - Global change biology 13(12): 2509-2537.

[23] Malhi, Y. A., Baldocchi, D. D., Jarvis, P. G. (1999): The carbon balance of tropical, temperate and boreal forests. - Plant, Cell \& Environment 22(6): 715-740.

[24] Nóbrega, G.N., Ferreira, T.O., Neto, M.S., Queiroz, H.M., Artur, A.G., De S. Mendonça, E., De O. Silva, E., Otero, X.L. (2016): Edaphic factors controlling summer (rainy season) greenhouse gas emissions $\left(\mathrm{CO}_{2}\right.$ and $\left.\mathrm{CH} 4\right)$ from semiarid mangrove soils (NEBrazil). - Science of the Total Environment 542: 685-693.

[25] Patra, P. K., et al. (2013): The carbon budget of South Asia. - Biogeosciences 10: 513527, doi:10.5194/bg-10-513-2013.

[26] Le Quéré, C., Raupach, M. R., Canadell, J. G., Marland, G., Bopp, L., Ciais, P., ... \& Friedlingstein, P. (2009): Trends in the sources and sinks of carbon dioxide. - Nature Geoscience 2(12): 831-836.

[27] Le Quéré, C., Peters, G. P., Andres, R. J., Andrew, R. M., Boden, T. A., Ciais, P., ... \& Sitch, S. (2014): Global carbon budget 2013. - Earth Syst. Sci. Data 6: 235-263.

[28] Richardson, J., Chatterjee, A., Jenerette, G.D. (2012): Optimum temperatures for soil respiration along a semiarid elevation gradient in southern California. - Soil Biology \& Biochemistry 46: 89-95.

[29] Sakin, E., Sakin, E.D. (2015): Harran Ovasının Killi Topraklarında Karbon Emisyonun Ölçülmesi. GAP VII. Tarım Kongresi 28 Nisan-01 Mayıs 2015. Sayfa 208-214, Şanlıurfa.

[30] Sakin, E. (2016): Seasonal variations of carbon emissions in uncultivated soils. - Oxid. Commun. 39 (2): 1374-1384.

[31] Sakin, E., Sakin, ED., Kızılgöz, İ., Seyrek, A. (2016): Orman Örtüsü Altındaki Toprakların Karbondioksit Emisyonunun Ölçülmesi. - Harran Tarım ve Gıda Bil. Derg. 20 (2):127-134.

[32] Trumbore, S. (2006): Carbon respired by terrestrial ecosystems-recent progress and challenges. - Global Change Biology 12(2): 141-153.

[33] TSMS(Turkish State Meteorological Service). (2016): Climate data of Sanliurfa City.

[34] Zhou, Z., Xu, M., Kang, F., Sun, O.J. (2015): Maximum temperature accounts for annual soil $\mathrm{CO}_{2}$ efflux in temperate forests of Northern China. - Nature Scientific Reports 5:12142, DOi: $10.1038 /$ srep12142.

[35] Wu, H.J., Lee, X.H. (2011): Short-term effects of rain on soil respiration in two New England forests. - Plant and Soil 338: 329-342. 